\title{
Prognostic Impact of TTF-1 Expression in Non-Squamous Non-Small-Cell Lung Cancer: A Meta-Analysis
}

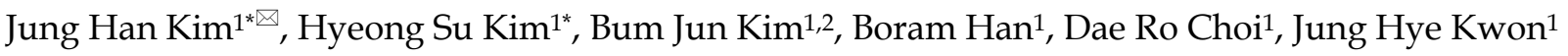 \\ 1. Division of Hemato-Oncology, Department of Internal Medicine, Hallym University Medical Center, Hallym University College of Medicine, Seoul, \\ Republic of Korea \\ 2. Department of Internal Medicine, National Army Capital Hospital, The Armed Forces Medical Command, Sungnam, Gyeonggi-Do, Republic of Korea \\ * JH Kim and HS Kim equally contributed to this work. \\ $\square$ Corresponding author: Jung Han Kim, MD, PhD. Division of Hemato-Oncology, Department of Internal Medicine, Kangnam Sacred-Heart Hospital, Hallym \\ University Medical Center, Hallym University College of Medicine, Seoul 07441, Republic of Korea. E-mail: harricil@hotmail.com, harricil@hallym.or.kr \\ (c) Ivyspring International Publisher. This is an open access article distributed under the terms of the Creative Commons Attribution (CC BY-NC) license \\ (https://creativecommons.org/licenses/by-nc/4.0/). See http://ivyspring.com/terms for full terms and conditions.
}

Received: 2018.04.22; Accepted: 2018.08.23; Published: 2018.10.20

\begin{abstract}
Thyroid transcription factor-1 (TTF-1) is overexpressed in up to $95 \%$ of primary lung adenocarcinoma while negative for almost all squamous cell carcinomas. TTF- 1 expression has been investigated as a prognostic factor in non-small-cell lung cancer (NSCLC) with conflicting results. We conducted this meta-analysis to gain a better insight into the prognostic role of TTF-1 in patients only with non-squamous (non-SQ) NSCLC. A systematic computerized search of the electronic databases including PubMed, PMC, EMBASE, Web of Science, and Cochrane Library was performed. From 21 studies, 6,451 patients were included in the combined analysis of hazard ratios (HRs) with $95 \%$ confidence intervals $(\mathrm{Cls})$ for overall survival. Compared with patients with non-SQ NSCLC showing negative TTF-1 expression, those with tumors harboring TTF-1 overexpression had significantly better survival $(\mathrm{HR}=0.49,95 \% \mathrm{Cl}: 0.42-0.57, \mathrm{p}<0.00001)$. Subgroup analyses revealed that TTF-1 expression significantly correlated with a better prognosis in stage I ( $H R=0.65$, 95\% Cl: 0.50-0.84, $\mathrm{p}=0.0008$ ) as well as stage III-IV non-SQ NSCLC (HR = 0.38, 95\% Cl: 0.29-0.49, $\mathrm{P}<0.00001)$. In conclusion, this meta-analysis demonstrates that TTF-1 overexpression is a favorable prognostic factor in patients with non-SQ NSCLC. The subgroup analyses indicate that TTF-1 is a good prognostic marker for survival not only in early-stage but also in advanced non-SQ NSCLC.
\end{abstract}

Key words: TTF-1; prognosis, non-small-cell lung cancer; meta-analysis

\section{Introduction}

Lung cancer remains the leading cause of cancer-related death worldwide [1,2], despite recent advances in diagnostic and therapeutic techniques. For patients with advanced or metastatic non-small-cell lung cancer (NSCLC), systemic chemotherapy can provide a modest but significant improvement of survival [3]. Systemic treatment for NSCLC has dramatically progressed with the introduction of molecular targeted agents in the last 15 years. Recently immune checkpoint inhibitors have emerged as a promising option in the treatment of advanced NSCLC [4].

Several clinical and disease-related factors have been suggested as independent prognostic factors for survival in NSCLC: performance status (PS), age, sex, weight loss, stage, histologic subtypes, and gene expression profiles $[5,6]$. For most of these factors, however, the discriminant value is insufficient to guide the optimal therapeutic strategy for an individual.

Thyroid transcription factor-1 (TTF-1) is a master regulatory transcription factor for tissue specific genes 
[7]. TTF-1 is normally expressed in the thyroid, lung, and brain during embryogenesis and plays a physiologic role in their development. In the normal lung, TTF-1 plays a decisive role in the maintenance of the functions of terminal respiratory unit cells [8]. TTF-1 expression by immunohistochemistry (IHC) in primary lung cancers is dependent on the histological subtypes, as demonstrated by $70-80 \%$ of adenocarcinomas (ADCs) and $80-90 \%$ of small-cell carcinoma while negative for virtually all squamous cell carcinomas (SQCCs). TTF-1 is commonly used to distinguish primary lung ADC from tumors of other sources that have metastasized to the lung. However, its role in the lung carcinogenesis remains unclear. An animal study demonstrated that upregulation of TTF-1 correlated with favorable survival and downregulation was linked to loss of differentiation, enhanced tumor seeding ability, and increased metastatic potential [9].

Although the role of TTF-1 as a marker for ADC in the differential diagnosis of primary lung cancers has been well documented, its prognostic significance in patients with NSCLC has still been inconclusive [11-36]. While Puglisi et al. observed a detrimental effect of TTF-1 expression in resected NSCLC [11], the relationship between TTF-1 and survival was not found in other observational studies $[12,14,16-19,23$, $27,31,32,37]$. However, others investigators reported that TTF-1 positivity was associated with a better prognosis $[13,15,20-22,25,26,28-30,33-36,38]$. These discrepant results indicate that the prognostic significance of TTF-1 in NSCLC remains controversial.

The previous meta-analyses reported that TTF-1 expression correlated with a better survival in NSCLC $[39,40]$. Although TTF-1 IHC staining is negative for almost all SQCCs, however, they included patients with this histological subtype of NSCLC in the analysis. Therefore, their results could not reflect exactly the prognostic significance of TTF-1 in non-squamous (non-SQ) NSCLC. We performed this updated meta-analysis to gain a better insight into the prognostic role of TTF-1 expression in patients only with non-SQ NSCLC.

\section{Materials and Methods}

\section{Publication searching strategy}

This meta-analysis was conducted according to the Preferred Reporting Items for Systematic Reviews and Meta-Analyses (PRISMA) guidelines [41]. A systematic computerized search of the electronic databases including PubMed, PMC, EMBASE, Web of Science, and Cochrane Library (up to July 2018) was performed. The search used the following terms variably combined: "thyroid transcription factor-1" or "TTF-1" AND "non-small-cell lung cancer" or "NSCLC" or "lung cancer". The related articles function in the PubMed was used to identify all relevant articles. The references reported in the identified studies were also reviewed to complete the search.

\section{Inclusion criteria}

Eligible studies should meet the following inclusion criteria: (i) patients with non-SQ NSCLC (ii) IHC test of TTF-1 expression in the primary lung cancer tissue; (iii) the use of adequate IHC methods for positive TTF-1 staining; (iv) prospective or retrospective cohort studies investigating the correlation of TTF-1 expression with overall survival (OS); (v) sufficient data for hazard ratio (HR) with 95\% confidence intervals (CI) for OS; (vi) articles written only in English.

\section{Data extraction}

Two investigators (BJK and HSK) extracted independently the data from each eligible article. If these two authors did not agree, the principle investigator (JHK) was consulted to settle the dispute through discussion.

The following data were extracted from the included studies: the first author, year of publication, country, inclusion period, sample size, disease stage, histology, cut-off criteria of TTF-1 expression, and survival data. When there were both univariate and multivariate analysis for survival, the data were extracted from multivariate analysis. If data were not reported in the original article, items were treated as "not available." We did not contact the authors of the primary study to request additional data.

\section{Statistical analysis}

The survival outcomes were stratified according to the status of TTF-1 expression (negative vs. positive). Statistical values were obtained directly from the original articles. When papers had no HR and its 95\% CI, the Engauge Digitizer software was used to estimate them from Kaplan-Meier curves. The RevMan version 5.3 was used to combine the data. For quantitative aggregation of the survival outcomes, HRs and their 95\% CIs were combined to give the effective value. Subgroup analysis was performed according to the disease stage (I or III-IV). The heterogeneity across studies was estimated by the $Q$ statistics and $I^{2}$ inconsistency test. The fixed-effect model (Mantel-Haenszel method) was used for pooling homogeneous outcomes $\left(\mathrm{p} \geq 0.1\right.$ and $I^{2} \leq$ $50 \%$ ), and the random-effects model (DerSimonianLaird method) was selected when significant 
heterogeneity was detected ( $\mathrm{p}<0.1$ or $I^{2}>50 \%$ ). The significance of the pooled HR and OR was determined by the Z-test, and an observed HR $<1.0$ implies better survival for patients with positive TTF-1 staining.

The possibility of publication bias was assessed with visual inspection of the funnel plot [42]. For quantitative analyses, Egger's linear regression test was performed using the statistical software packages $\mathrm{R}$ (www.r-project.org) [43]. Statistical significance was considered for a p-value of less than 0.05 for summary $\mathrm{HR}$ and publication biases.

\section{Results}

\section{Results of search}

A total of 880 potentially relevant articles were initially found, but 835 of them were excluded after careful screening of the titles and abstracts. Of the remaining 45 potentially eligible studies, 24 were further excluded by the inclusion criteria. Finally, 21 studies were included in the meta-analysis [18-38]. Figure 1 shows the search flow diagram of this meta-analysis.

\section{Characteristics of the included studies}

Table 1 summarizes the main characteristics and survival outcomes of the 21 studies. Except for eight with a prospective cohort [20-22,25,28,29,33,37], thirteen were retrospective studies. One study was conducted in two independent cohorts [21]. The IHC cut-off criteria for positive TTF-1 staining were variable across studies. Frequencies of TTF-1

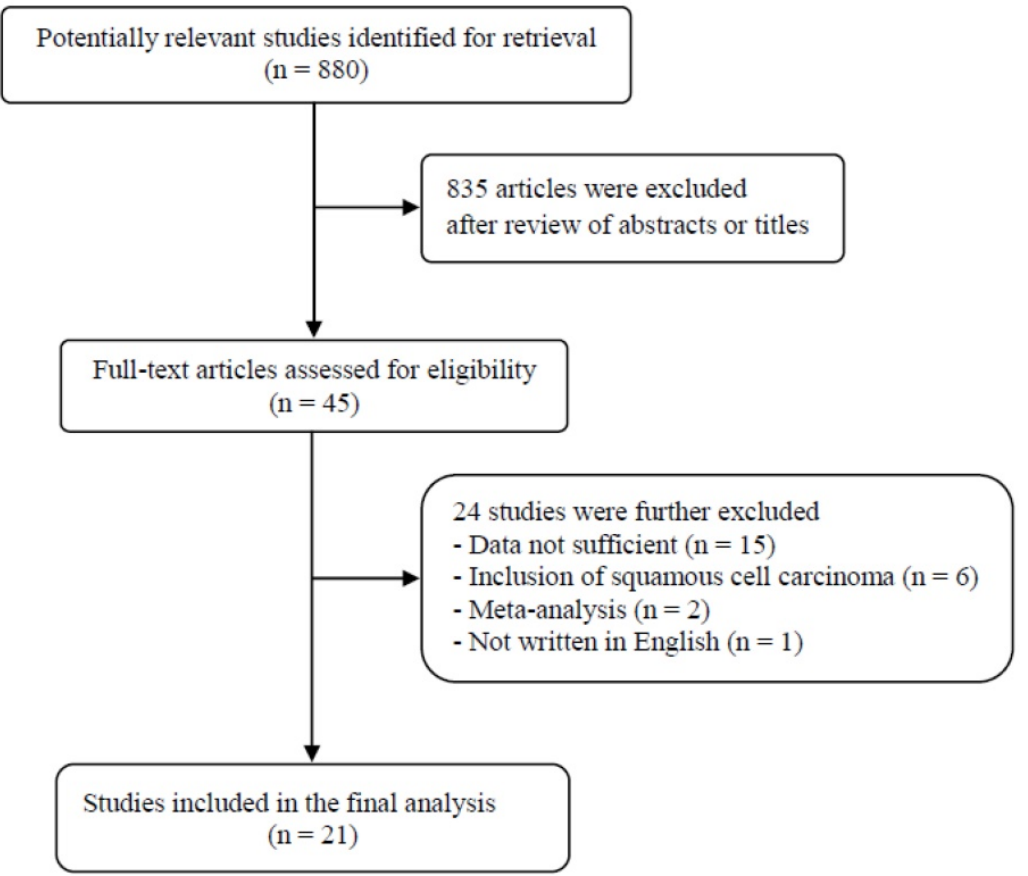

Figure 1. Flow diagram of search process expression in the included studies ranged from $12.2 \%$ [23] to $95.5 \%$ [37]. While three studies contained non-SQ NSCLC [26,31,34], 18 studies only involved ADC [18-25,26-30,32,33,35-38]. Three studies involved patients only with stage I ADC $[18,19,37]$ and nine involved patients with advanced (stage III-IV) [20, 22, $26,29,31,34,36,38]$. Fourteen studies reported positive TTF-1 staining as a favorable prognostic factor [20-22,24-26,28-30,33-36,38] and the remaining 7 studies failed to observe statistically significant impact of TTF-1 expression on survival $[18,19,23,27$, $31,32,37]$.

\section{Prognostic impact of TTF-1 expression}

\section{Impact of TTF-1 expression on survival}

From 21 studies [18-38], a total of 6,451 patients were included in the meta-analysis of HRs for OS. There was a considerable heterogeneity among studies $\left(X^{2}=36.29, p=0.02, I^{2}=42 \%\right)$. Compared with patients with non-SQ NSCLC showing negative TTF-1 staining, patients with non-SQ tumors harboring positive TTF-1 expression showed significantly better survival $(\mathrm{HR}=0.49,95 \% \mathrm{CI}: 0.42-0.57, \mathrm{p}<0.00001$, random-effects model) (Figure 2).

\section{Subgroup-analyses according to the disease stage}

When we pooled HRs for OS according to the stage, the combined HRs were 0.65 (95\% CI: 0.50-0.84, $p=0.0008, I^{2}=0 \%$, fixed-effect model) for stage $I$ (Figure 3A) and 0.38 (95\% CI: 0.29-0.49, p < 0.00001, $I^{2}$ $=48 \%$, random-effects model) for stage III-IV (Figure $3 \mathrm{~B})$, indicating better prognosis in tumors showing TTF-1 expression not only in early-stage but also in advanced non-SQ NSCLC.

\section{Publication bias}

Visual inspection of the funnel plot for OS showed symmetry, indicating there was no substantial publication bias (Figure 4). Egger's test also indicated no evidence of substantial publication bias $(\mathrm{p}$ $=0.145$ ).

\section{Discussion}

In clinical practice, TTF-1 is most commonly used to distinguish primary lung ADC from non-pulmonary cancers that have metastasized to the lung [44]. TTF-1 expression by IHC has been detected in up to $95 \%$ of ADC of the lung, depending on the techniques, cut-off value of positive staining, and stage $[29,37]$. However, the vast majority of SQ NSCLCs and most extrapulmonary tumors lack TTF-1 expression [45]. 
Table 1. Summary of the 21 included studies

\begin{tabular}{|c|c|c|c|c|c|c|c|c|c|c|}
\hline $\begin{array}{l}\text { First author } \\
\text { (year) [ref] }\end{array}$ & Country & $\begin{array}{l}\text { Study } \\
\text { design }\end{array}$ & $\begin{array}{l}\text { No. } \\
\text { of } \\
\text { pts }\end{array}$ & $\begin{array}{l}\text { Inclusion } \\
\text { period }\end{array}$ & Histology & Stage & $\begin{array}{l}\text { IHC criteria for TTF-1 }(+) \text { : } \\
\text { nuclear staining }\end{array}$ & $\begin{array}{l}\text { No. of pts } \\
\text { with TTF-1 (+) } \\
(\%)\end{array}$ & $\begin{array}{l}\text { HR for OS } \\
(95 \% \mathrm{CI})\end{array}$ & Adjusted variables \\
\hline $\begin{array}{l}\text { Pelosi } \\
(2001)[18]\end{array}$ & Italy & Retro & 97 & $1987-1993$ & $\mathrm{ADC}$ & I & $\begin{array}{l}\text { More intense to the internal } \\
\text { control }\end{array}$ & $70(72.2 \%)$ & $\begin{array}{l}0.92(0.48-1.73) \\
p=0.7854\end{array}$ & Univariate \\
\hline $\begin{array}{l}\text { Saad } \\
(2004)[19]\end{array}$ & USA & Retro & 50 & $1996-2000$ & $\mathrm{ADC}$ & I & $\begin{array}{l}\text { Percentage } x \text { intensity } \geq 50 \\
\text { positive tumor cells }\end{array}$ & $30(60 \%)$ & $\begin{array}{l}0.68(0.45-1.01) \\
p=0.0583\end{array}$ & Univariate \\
\hline $\begin{array}{l}\text { Barlesi } \\
(2005)[20]\end{array}$ & France & Pro & 106 & $2002-2004$ & $\mathrm{ADC}$ & III-IV & Sole nuclear staining & $70(66 \%)$ & $\begin{array}{l}0.40(0.25-0.65) \\
p=0.0002\end{array}$ & Univariate \\
\hline $\begin{array}{l}\text { Anagnostou, } \\
\text { Cohort I } \\
(2009)[21]\end{array}$ & USA & Pro & $\begin{array}{l}89 \\
(43)\end{array}$ & $1995-2003$ & $\mathrm{ADC}$ & $\begin{array}{l}\text { I-IV } \\
\text { (I) }\end{array}$ & Nuclear AQUA score $>8.8$ & $\begin{array}{l}56(62.9 \%) \\
(30)\end{array}$ & $\begin{array}{l}0.54(0.29-7-0.98) \\
p=0.041 \\
0.39(0.14-1.11) \\
p=0.079\end{array}$ & Age, sex, stage \\
\hline $\begin{array}{l}\text { Anagnostou } \\
\text { Cohort II } \\
(2009)[21]\end{array}$ & USA & Pro & $(87)$ & $1995-2003$ & $\mathrm{ADC}$ & $\begin{array}{l}\text { I-IV } \\
\text { (I) }\end{array}$ & Nuclear AQUA score $>8.8$ & $\begin{array}{l}72(73.5 \%) \\
(65)\end{array}$ & $\begin{array}{l}0.53(0.26-7-1.05) \\
p=0.07 \\
0.48(0.24-0.98) \\
p=0.043\end{array}$ & Age, sex, stage \\
\hline $\begin{array}{l}\text { Martins } \\
(2009)[22]\end{array}$ & Brazil & Pro & 51 & 1997-1999 & $\mathrm{ADC}$ & IIIB-IV & $>40 \%$ of tumor cells & $20(39.2 \%)$ & $\begin{array}{l}0.25(0.11-0.57) \\
p=0.001\end{array}$ & PS, MMP-9 \\
\hline $\begin{array}{l}\text { Anami } \\
(2009)[23]\end{array}$ & Japan & Retro & 139 & $1993-2000$ & $\begin{array}{l}\text { Small ADC } \\
(<2 \mathrm{~cm})\end{array}$ & I-III & $\geq 50 \%$ of tumor cells & $17(12.2 \%)$ & $\begin{array}{l}0.405(0.10-1.69) \\
p=0.215\end{array}$ & Univaritate \\
\hline $\begin{array}{l}\text { Barletta } \\
(2009)[24]\end{array}$ & USA & Retro & 89 & 1997-1999 & $\mathrm{ADC}$ & I-IV & $\begin{array}{l}\text { No staining }(0), \text { weak } \\
\text { staining }(1) \text {, and strong } \\
\text { staining (2) (positive: } 1 \text { or } 2)\end{array}$ & $46(51.7 \%)$ & $0.39(0.21-0.72)$ & Univariate \\
\hline $\begin{array}{l}\text { Hiramatsu } \\
(2010)[25]\end{array}$ & Japan & Pro & 193 & $1998-2001$ & $\mathrm{ADC}$ & I-IV & $\begin{array}{l}\text { Stronger than xenograft } \\
\text { staining }\end{array}$ & $154(79.8 \%)$ & $\begin{array}{l}0.28(0.15-0.54) \\
p<0.001\end{array}$ & $\begin{array}{l}\text { Sex, stage, pAkt, } \\
\text { pFKHR }\end{array}$ \\
\hline $\begin{array}{l}\text { Sun } \\
(2011)[26]\end{array}$ & Korea & Retro & 284 & $2007-2010$ & Non-SQCC & IIIB-IV & $\begin{array}{l}\text { Percentage }(0-100 \%) x \\
\text { intensity }(0-2) \geq 10\end{array}$ & $194(68.3 \%)$ & $\begin{array}{l}0.55(0.39-0.77) \\
p=0.0005\end{array}$ & $\begin{array}{l}\text { Age, sex, smoking, } \\
\text { PS, histology }\end{array}$ \\
\hline $\begin{array}{l}\text { Solis } \\
(2012) \text { [27] }\end{array}$ & USA & Retro & 135 & $1997-2005$ & $\begin{array}{l}\text { ADC with } \\
\text { non-solid }\end{array}$ & I-IV & $\begin{array}{l}\text { Percentage }(0-100 \%) x \\
\text { intensity }(0-4)>160\end{array}$ & $59(43.7 \%)$ & $\begin{array}{l}0.70(0.48-1.04) \\
p=0.0749\end{array}$ & Univariate \\
\hline $\begin{array}{l}\mathrm{Li} \\
(2012)[28]\end{array}$ & China & Pro & 175 & $2000-2006$ & ADC & I-IV & $\begin{array}{l}\geq 30 \% \text { of tumor cells with } \\
\text { weak staining intensity }\end{array}$ & $57(32.6 \%)$ & $\begin{array}{l}0.41(0.24-0.67) \\
p<0.001\end{array}$ & Univariate \\
\hline $\begin{array}{l}\text { Chung } \\
(2013)[29]\end{array}$ & China & Pro & 496 & 2004-2009 & $\mathrm{ADC}$ & IIIB-IV & $\begin{array}{l}\text { Any definite nuclear } \\
\text { staining }\end{array}$ & $443(89.3 \%)$ & $0.45(0.30-0.67)$ & $\begin{array}{l}\text { Age, PS, stage, } \\
\text { metastases, EGFR } \\
\text { mutation, TKI } \\
\text { treatment }\end{array}$ \\
\hline $\begin{array}{l}\text { Nagashio } \\
(2015)[30]\end{array}$ & Japan & Retro & 198 & $2002-2005$ & $\mathrm{ADC}$ & I-III & $\begin{array}{l}\text { Moderate intensity in } \geq 10 \% \\
\text { of tumor cells }\end{array}$ & $161(81.3 \%)$ & $\begin{array}{l}0.60(0.42-0.85) \\
p=0.0044\end{array}$ & Univariate \\
\hline $\begin{array}{l}\text { Elsamany } \\
(2015)[31]\end{array}$ & Egypt & Retro & 120 & 2011-2012 & Non-SQCC & IIIB-IV & NA & $100((83.3 \%)$ & $\begin{array}{l}0.43(0.16-1.18) \\
p=0.10\end{array}$ & $\begin{array}{l}\text { Sex, chemotherapy, } \\
\text { EGFR mutations }\end{array}$ \\
\hline $\begin{array}{l}\text { Zhao } \\
(2015) \text { [32] }\end{array}$ & Taiwan & Retro & 200 & $2008-2013$ & $\mathrm{ADC}$ & I-IV & $\geq 10 \%$ of tumor cells & $163(81.5 \%)$ & $\begin{array}{l}0.74(0.39-1.41) \\
p=0.365 \\
\text { III-IV: } 0.48 \\
(0.24-0.95) \\
p=0.036\end{array}$ & EGFR mutations \\
\hline $\begin{array}{l}\text { Zhang } \\
(2015) \text { [33] }\end{array}$ & China & Pro & 451 & $2008-2013$ & $\mathrm{ADC}$ & I-III & $\begin{array}{l}\text { Any positive nuclear } \\
\text { staining }\end{array}$ & $332(73.6 \%)$ & $\begin{array}{l}0.64(0.42-0.99) \\
P=0.043\end{array}$ & $\begin{array}{l}\text { Sex, smoking, } \\
\text { subtypes, stage, LN } \\
\text { status, EGFR } \\
\text { mutation }\end{array}$ \\
\hline $\begin{array}{l}\text { Nakahara } \\
(2016)[34]\end{array}$ & Japan & Retro & 26 & $2008-2013$ & $\begin{array}{l}\text { Non-SQCC } \\
\text { EGFR WT }\end{array}$ & IV & Evident nuclear staining & $20(76.9 \%)$ & $\begin{array}{l}0.10(0.02-0.43) \\
p=0.002\end{array}$ & Univariate \\
\hline $\begin{array}{l}\text { Piljić } \\
\text { Burazer } \\
(2017)[35]\end{array}$ & Croatia & Retro & 118 & 2013-2014 & $\mathrm{ADC}$ & I-IV & $\begin{array}{l}\text { Homogeneous nuclear } \\
\text { staining in any cell }\end{array}$ & $96(81.3 \%)$ & $\begin{array}{l}0.50(0.29-0.85) \\
p=0.011\end{array}$ & Univariate \\
\hline $\begin{array}{l}\text { Schilsky } \\
(2017)[36]\end{array}$ & USA & Retro & 479 & 2009-2011 & $\mathrm{ADC}$ & IV & Any nuclear reactivity & $383(79.9 \%)$ & $\begin{array}{l}0.38(0.29-0.51) \\
p<0.0001\end{array}$ & $\begin{array}{l}\text { Age, sex, smoking, } \\
\text { PS, molecular } \\
\text { subgroups, } \\
\text { treatment }\end{array}$ \\
\hline $\begin{array}{l}\text { Zhou } \\
(2017) \text { [37] }\end{array}$ & China & Pro & 2,813 & $2010-2015$ & $\mathrm{ADC}$ & I & Sole nuclear staining & $2,687(95.5 \%)$ & $\begin{array}{l}0.60(0.30-1.21) \\
p=0.152\end{array}$ & Univariate \\
\hline $\begin{array}{l}\text { Doherty } \\
(2018)[38]\end{array}$ & Ireland & Retro & 44 & $2008-2013$ & $\mathrm{ADC}$ & IV & $\begin{array}{l}\geq 1 \% \text { nuclear staining (not } \\
\text { membranous or } \\
\text { cytoplasmic) }\end{array}$ & $9(20.4 \%)$ & $\begin{array}{l}0.12(0.04-0.35) \\
p<0.0001\end{array}$ & Univariate \\
\hline
\end{tabular}

NSCLC, non-small-cell lung cancer; Pro, prospective; Retro, retrospective; ADC, adenocarcinoma; SQCC, squamous cell carcinoma; AQUA, automated quantitative analysis; MMP-9, matrix metalloproteinase-9; pAkt, phosphorylated Akt; pFKHR, phosphorylated forkhead transcription factor; EGFR, epidermal growth factor receptor; WT, wild type; PS, performance status; pts, patients; HR, hazard ratio; CI, confidence interval; OS, overall survival; IHC, immunohistochemistry; LN, lymph node; NA, not available 


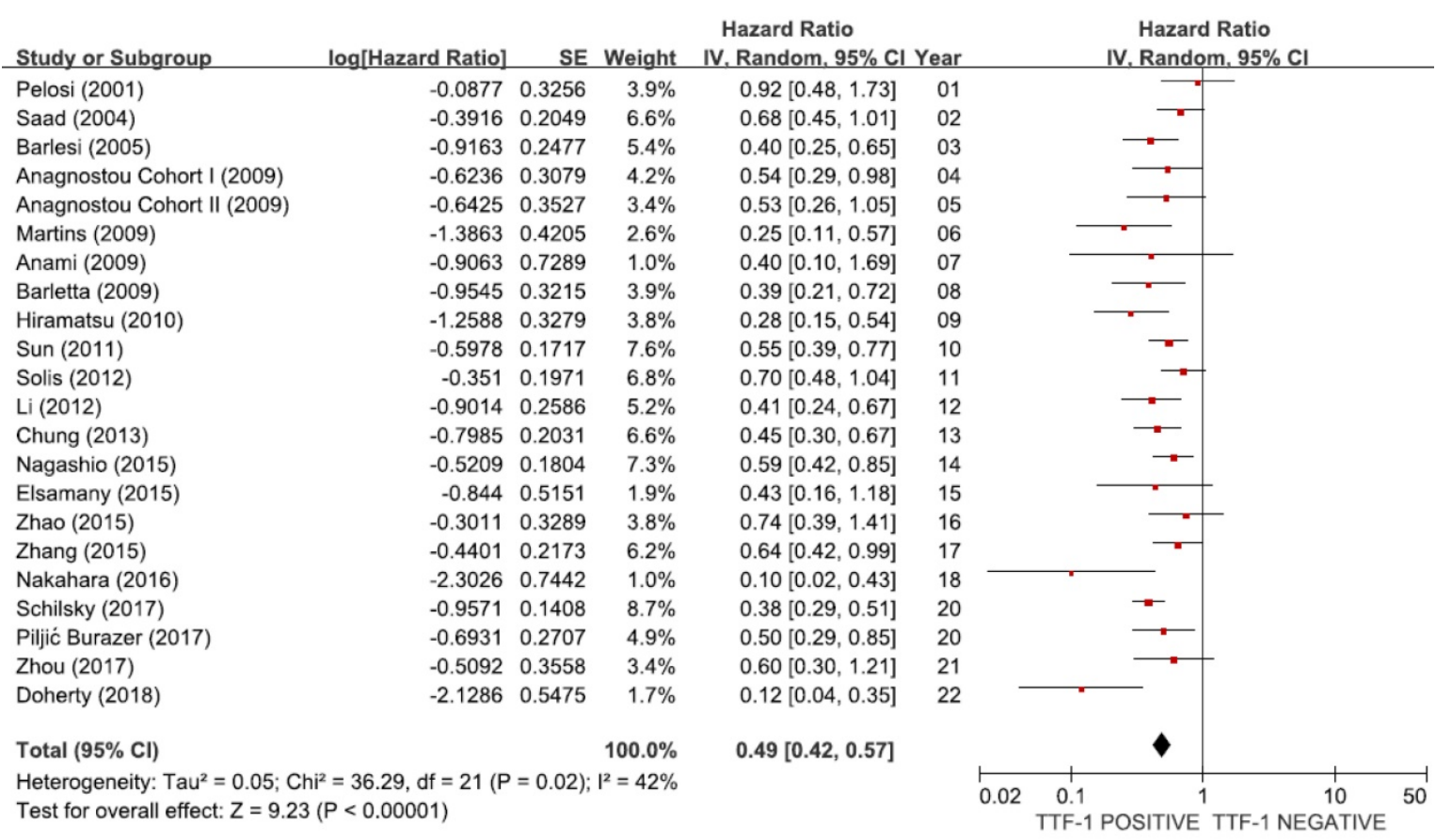

Figure 2. Meta-analysis (forest plot) of 21 studies assessing the prognostic impact of TTF-1 in non-SQ NSCLC.

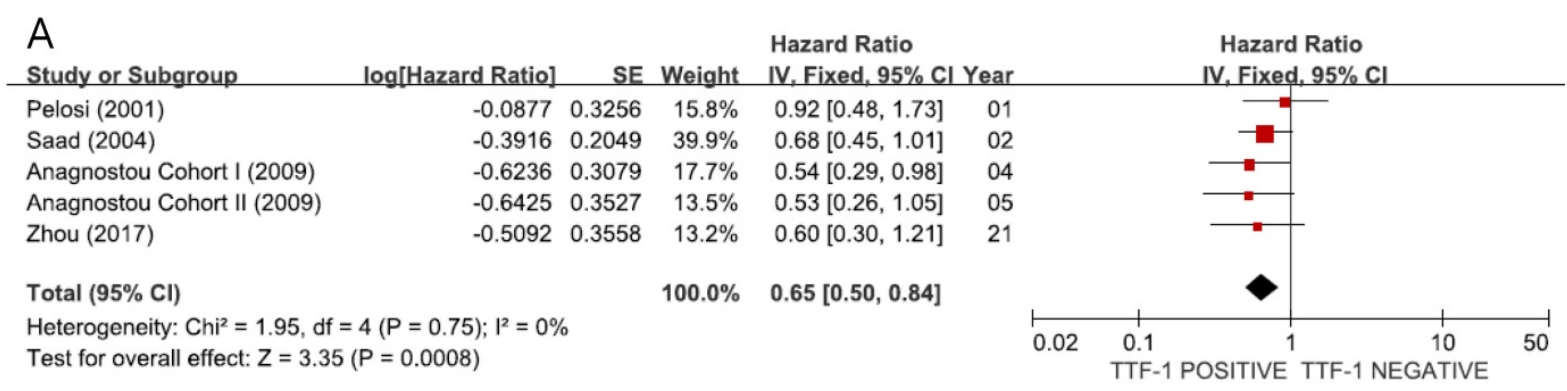

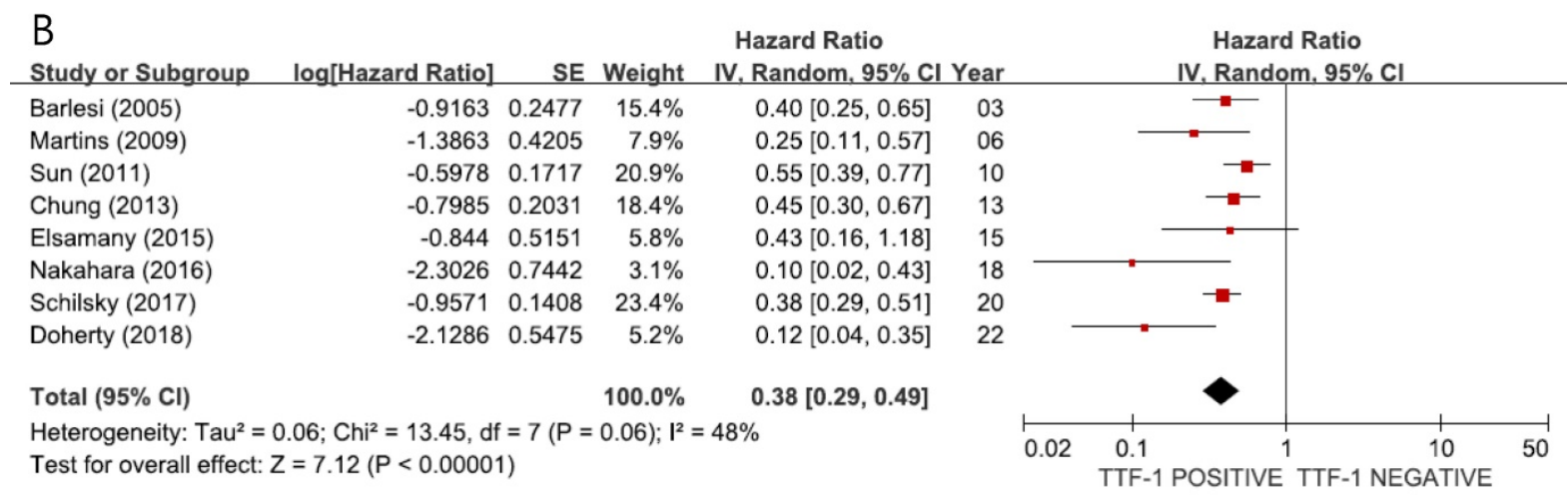

Figure 3. Subgroup meta-analyses (forest plots) assessing the prognostic impact of TTF-1 in stage I (A) and stage III-IV (B) non-SQ NSCLC

The first meta-analysis in 2006 by Berghmans et al. combined 8 studies [12,14-20] and observed that TTF-1 positivity was associated with better survival in NSCLC (HR $=0.64,95 \%$ CI: 0.41-1.00) [39]. As there was one study incorporating stage IV, however, the prognostic impact of TTF-1 was demonstrated only in early or locally advanced stages (stage I-III). Qian et al. published in 2015 the second meta-analysis of 17 studies with 2,235 NSCLC patients [40]. They observed that TTF-1 overexpression had a favorable impact on survival of patients with NSCLC (HR = 0.49 , 95\% CI: $0.42-0.55, \mathrm{p}=0.001)$. The subgroup analysis showed that the favorable prognostic impact remained significant regardless of ethnicity: $\mathrm{HR}=0.52$ (95\% CI: 0.42-0.63) for Asian and HR $=0.45$ (95\% CI: $0.38-0.52)$ for non-Asian. This effect was also 
significant when the analysis was restricted to stage I (HR $=0.63$, 95 CI: 0.39-0.86) or stage III-IV (HR $=0.43$, 95\% CI: 0.33-0.53). However, they included SQ NSCLC with virtually no potential of TTF-1 expression. Therefore, their results might not reflect the actual prognostic impact of TTF-1 in non-SQ NSCLC.

In the current meta-analysis, we investigated the prognostic value of TTF-1 expression in patients only with non-SQ NSCLC. We combined 21 published studies including 6,451 patients to yield summary statistics. The result revealed that TTF-1 expression had a significant correlation with favorable survival in patients with non-SQ NSCLC $(\mathrm{HR}=0.49, \mathrm{p}<0.00001)$. Subgroup analysis demonstrated that TTF-1 overexpression had a significant favorable impact on survival in stage I $(\mathrm{HR}=0.65, \mathrm{p}=0.0008)$. Because most patients included in our study did not receive adjuvant therapy, this finding indicates that TTF-1 can be an independent prognostic factor to delineate those who need to be further treated after surgery for patients with early-stage non-SQ NSCLC. In addition, when the analysis was restricted to stage III-IV, the prognostic impact of TTF-1 remained significant with the lower combined HR $(0.38, p<0.00001)$. These findings suggest that TTF- 1 is a good prognostic marker for survival not only in early-stage but also in advanced non-SQ NSCLC. On the basis of the results from the current meta-analysis, TTF-1 needs to be selected for prospective studies with multivariate analysis including the known prognostic factors in NSCLC such as PS and stage.

The reasons why TTF-1 is associated with prognosis of patients with non SQ NSCLC (mainly ADC) are unclear. Myong reported that TTF-1 expression was inversely related to the proliferative activity evaluated through Ki-67 expression [16].

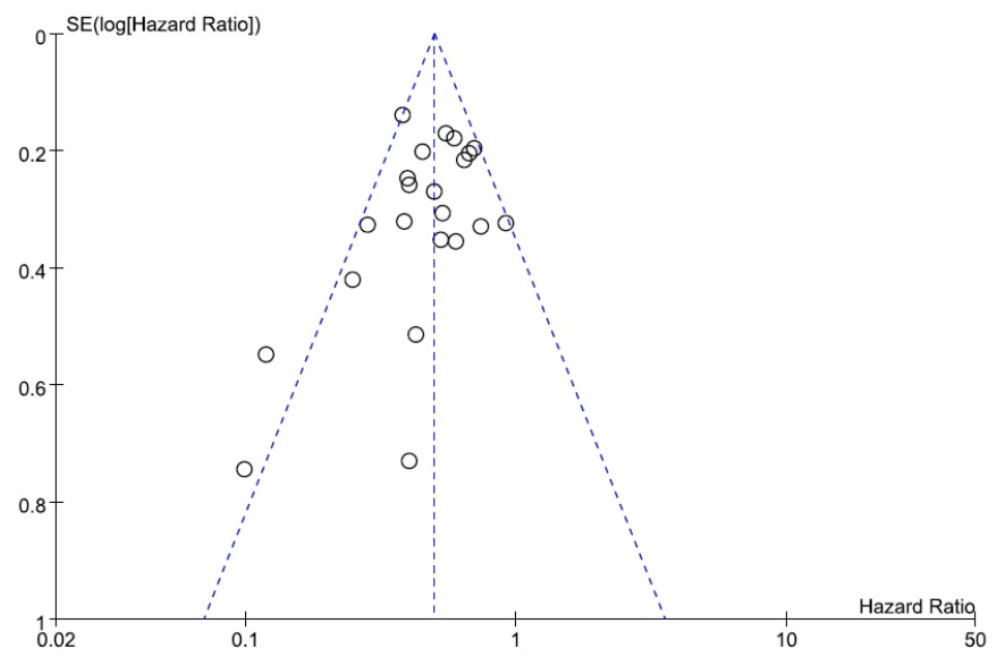

Figure 4. Funnel plot for publication bias regarding overall survival.
Some investigators have suggested that there is a relationship between epidermal growth factor receptor (EGFR) mutations and TTF-1 expression in lung ADCs [32,36,46-48]. The NEJ 002 clinical trial reported that the rate of EGFR mutations was significantly higher in ADC specimens with positive TTF-1 expression than in specimens with no TTF-1 expression [46]. Shanzhi et al. found that positive and partial positive TTF-1 expression has a significant positive correlation with EGFR mutations (exon 19 and 21) in lung ADCs [46]. Recently Zhao et al. also reported a significant association between TTF-1 positivity and EGFR mutations (exon 21) in the Chinese lung ADC patients [32]. Of 89 patients with EGFR mutations, 83 (93\%) specimens were simultaneously positive for TTF-1 expression ( $\mathrm{p}<$ 0.001 by the $\chi^{2}$ test). In addition, patients with stage III-IV whose tumors were positive for TTF-1 expression and EGFR mutations had better postoperative survival than those with tumors harboring neither TTF-1 expression nor EGFR mutations ( $\mathrm{HR}=2.62,95 \% \mathrm{CI}: 1.09-6.31, \mathrm{p}=0.027)$. These results suggest that in clinical practice, TTF-1 expression combined with EGFR mutations can guide treatment timely for patients with lung ADCs.

Our study has several inherent limitations. First, the included studies showed considerable diversities in the techniques used for IHC. They used un-identical monoclonal antibodies at different concentration and dissimilar staining protocol. In addition, the cut-off criteria for positive TTF-1 staining was also various among studies. The wide range of incidence of TTF-1 positivity among studies (from $12.2 \%$ to $95.5 \%$ ) might be attributable to the different IHC methods and criteria for TTF-1 overexpression. Therefore, it is still necessary to define the standardized methods to evaluate exactly the prognostic role of TTF-1 in non-SQ NSCLC. Second, this meta-analysis included the studies with non-SQ NSCLC regardless of EGFR mutation status. EGFR mutation is the strongest prognostic factor in non-SQ NSCLC. However, we could not evaluate the prognostic impact of TTF-1 according to the EGFR mutation status due to the insufficient data. Third, more than half studies were retrospectively performed and therefore might carry the biases of the retrospective design. Fourth, as we mentioned above, there were two meta-analyses regarding the prognostic impact of TTF-1 in NSCLC in the literature $[39,40]$. They included all subtypes of NSCLC from studies published between 1999 and 2012. However, we have improved upon the previous meta-analyses by adding 
10 more recent studies published after 2013 [29-38] and the meta-analysis was performed in patients only with non-SQ NSCLC. Therefore, we assume that our results reflect more actually the prognostic impact of TTF-1 in non-SQ NSCLC. Finally, articles published only in English were included, which might bias the results.

In conclusion, this meta-analysis indicates that TTF-1 overexpression is a favorable prognostic factor in patients with non-SQ NSCLC. Its prognostic impact is also significant when the subgroup analysis is restricted to stage I or stage III-IV non-SQ NSCLC. However, large prospective studies using standardized IHC criteria based on the homogeneous populations are warranted to validate the prognostic value of TTF-1 expression in patients with non-SQ NSCLC.

\section{Competing Interests}

The authors have declared that no competing interest exists.

\section{References}

1. Jung KW, Won YJ, Kong HJ, Lee ES; Community of Population-Based Regional Cancer Registries. Cancer statistics in Korea: incidence, mortality, survival, and prevalence in 2015. Cancer Res Treat. 2018; 50: 303-16.

2. Ferlay J, Soerjomataram I, Dikshit R, Eser S, Mathers C, Rebelo M, et al. Cancer incidence and mortality worldwide: sources, methods and major patterns in GLOBOCAN 2012. Int J Cancer. 2015; 136: 359-86.

3. NSCLC Meta-Analyses Collaborative Group. Chemotherapy in addition to supportive care improves survival in advanced non-small-cell lung cancer: a systematic review and meta-analysis of individual patient data from 16 randomized controlled trials. J Clin Oncol. 2008; 26: 4617-25.

4. Chen YM. Immune checkpoint inhibitors for nonsmall cell lung cancer treatment. J Chin Med Assoc. 2017; 80: 7-14.

5. Paesmans M, Sculier JP, Libert P, Bureau G, Dabouis G, Thiriaux J, et al. Prognostic factors for survival in advanced non-small-cell lung cancer: univariate and multivariate analyses including recursive partitioning and amalgamation algorithms in 1,052 patients. The European Lung Cancer Working Party. J Clin Oncol. 1995; 13: 1221-30.

6. Chen T, Chen L. Prediction of clinical outcome for all stages and multiple cell types of non-small cell lung cancer in five countries using lung cancer prognostic index. EBioMedicine. 2014; 1: 156-66.

7. Guazzi S, Price M, De Felice M, Damante G, Mattei MG, Di Lauro R. Thyroid nuclear factor 1 (TTF-1) contains a homeodomain and displays a novel DNA binding specificity. EMBO J. 1990; 9: 3631-9.

8. Zhang L, Whitsett JA, Stripp BR. Regulation of Clara cell secretory protein gene transcription by thyroid transcription factor-1. Biochim Biophys Acta. 1997; 1350: 359-67.

9. Winslow MM, Dayton TL, Verhaak RG, Kim-Kiselak C, Snyder EL, Feldser $\mathrm{DM}$, et al. Suppression of lung adenocarcinoma progression by Nkx2-1. Nature. 2011; 473: 101-4

10. Stenhouse G, Fyfe N, King G, Chapman A, Kerr KM. Thyroid transcription factor 1 in pulmonary adenocarcinoma. J Clin Pathol. 2004; 57: 383-7.

11. Puglisi F, Barbone F, Damante G, Bruckbauer M, Di Lauro V, Beltrami CA, Di Loreto C. Prognostic value of thyroid transcription factor-1 in primary, resected, non-small cell lung carcinoma. Mod Pathol. 1999; 12:318-24.

12. Maneechawakajorn J, Benjawongsathien D. Prognostic role of thyroid transcription factor-1 (TTF-1) in advanced and inoperable adenocarcinoma subtype of lung cancer among Thai patients. J Med Assoc Thai. 2014; 97: S11-7.

13. Grønberg $\mathrm{BH}$, Lund-Iversen $\mathrm{M}$, Strøm $\mathrm{EH}$, Brustugun OT, Scott $\mathrm{H}$. Associations between TS, TTF-1, FR- $\alpha$, FPGS, and overall survival in patients with advanced non-small-cell lung cancer receiving pemetrexed plus carboplatin or gemcitabine plus carboplatin as first-line chemotherapy. J Thorac Oncol. 2013; 8: 1255-64.

14. Haque AK, Syed S, Lele SM, Freeman DH, Adegboyega PA. Immunohistochemical study of thyroid transcription factor-1 and HER2/neu in non-small cell lung cancer: strong thyroid transcription factor-1 expression predicts better survival. Appl Immunohistochem Mol Morphol. 2002; 10: 103-9.

15. Tan D, Li Q, Deeb G, Ramnath N, Slocum HK, Brooks J, et al. Thyroid transcription factor-1 expression prevalence and its clinical implications in non-small cell lung cancer: a high-throughput tissue microarray and immunohistochemistry study. Hum Pathol. 2003; 34: 597-604.

16. Myong NH. Thyroid transcription factor-1 (TTF-1) expression in human lung carcinomas: its prognostic implication and relationship with wxpressions of p53 and Ki-67 proteins. J Korean Med Sci. 2003; 18: 494-500.

17. Shah L, Walter KL, Borczuk AC, Kawut SM, Sonett JR, Gorenstein LA, et al. Expression of syndecan-1 and expression of epidermal growth factor receptor are associated with survival in patients with nonsmall cell lung carcinoma. Cancer. 2004; 101: 1632-8.

18. Pelosi G, Fraggetta F, Pasini F, Maisonneuve P, Sonzogni A, Iannucci A, et al. Immunoreactivity for thyroid transcription factor-1 in stage I non-small cell carcinomas of the lung. Am J Surg Pathol. 2001; 25: 363-72.

19. Saad RS, Liu YL, Han H, Landreneau RJ, Silverman JF. Prognostic significance of thyroid transcription factor-1 expression in both early-stage conventional adenocarcinoma and bronchioloalveolar carcinoma of the lung. Hum Pathol. 2004; 35: 3-7.

20. Barlési F, Pinot D, Legoffic A, Doddoli C, Chetaille B, Torre JP, Astoul P. Positive thyroid transcription factor 1 staining strongly correlates with survival of patients with adenocarcinoma of the lung. Br J Cancer. 2005; 93: 450-2.

21. Anagnostou VK, Syrigos KN, Bepler G, Homer RJ, Rimm DL. Thyroid transcription factor 1 is an independent prognostic factor for patients with stage I lung adenocarcinoma. J Clin Oncol. 2009; 27: 271-8.

22. Martins SJ, Takagaki TY, Silva AG, Gallo CP, Silva FB, Capelozzi VL. Prognostic relevance of TTF-1 and MMP-9 expression in advanced lung adenocarcinoma. Lung Cancer. 2009; 64: 105-9.

23. Anami Y, Iijima T, Suzuki K, Yokota J, Minami Y, Kobayashi $\mathrm{H}$, et al. Bronchioloalveolar carcinoma (lepidic growth) component is a more useful prognostic factor than lymph node metastasis. J Thorac Oncol. 2009; 4: 951-8.

24. Barletta JA, Perner S, Iafrate AJ, Yeap BY, Weir BA, Johnson LA, et al. Clinical significance of TTF-1 protein expression and TTF-1 gene amplification in lung adenocarcinoma. J Cell Mol Med. 2009; 13: 1977-86.

25. Hiramatsu M, Ninomiya H, Inamura K, Nomura K, Takeuchi K, Satoh Y, et al. Activation status of receptor tyrosine kinase downstream pathways in primary lung adenocarcinoma with reference of KRAS and EGFR mutations. Lung Cancer. 2010; 70: 94-102.

26. Sun JM, Han J, Ahn JS, Park K, Ahn MJ. Significance of thymidylate synthase and thyroid transcription factor 1 expression in patients with nonsquamous non-small cell lung cancer treated with pemetrexed-based chemotherapy. J Thorac Oncol. 2011; 6: 1392-9.

27. Solis LM, Behrens C, Raso MG, Lin HY, Kadara H, Yuan P, et al. Histologic patterns and molecular characteristics of lung adenocarcinoma associated with clinical outcome. Cancer. 2012; 118: 2889-99.

28. Li X, Wan L, Shen H, Geng J, Nie J, Wang G, et al. Thyroid transcription factor-1 amplification and expressions in lung adenocarcinoma tissues and pleural effusions predict patient survival and prognosis. J Thorac Oncol. 2012; 7: 76-84.

29. Chung KP, Huang YT, Chang YL, Yu CJ, Yang CH, Chang YC, et al. Clinical significance of thyroid transcription factor-1 in advanced lung adenocarcinoma under epidermal growth factor receptor tyrosine kinase inhibitor treatment. Chest. 2012; 141: 420-8.

30. Nagashio R, Ueda J, Ryuge S, Nakashima H, Jiang SX, Kobayashi M, et al. Diagnostic and prognostic significances of MUC5B and TTF-1 expressions in resected non-small cell lung cancer. Sci Rep. 2015; 5: 8649.

31. Elsamany SA, Al-Fayea TM, Alzahrani AS, Abozeed WN, Darwish W, Farooq $\mathrm{MU}$, et al. Thyroid transcription factor-1 expression in advanced non- small cell lung cancer: impact on survival outcome. Asian Pac J Cancer Prev. 2015; 16: 2987-91.

32. Zhao Q, Xu S, Liu J, Li Y, Fan Y, Shi T, et al. Thyroid transcription factor-1 expression is significantly associated with mutations in exon 21 of the epidermal growth factor receptor gene in Chinese patients with lung adenocarcinoma. Onco Targets Ther. 2015; 8: 2469-78.

33. Zhang Y, Wang R, Li Y, Pan Y, Hu H, Zhang Y, et al. Negative thyroid tanscription factor 1 expression defines an unfavorable subgroup of lung adenocarcinomas. J Thorac Oncol. 2015; 10: 1444-50.

34. Nakahara Y, Hosomi Y, Saito M, Ogawa M, Hishima T, Okamura T, et al. Predictive significance of thyroid transcription factor-1 expression in patients with non-squamous non-small cell lung cancer with wild-type epidermal growth factor receptor treated with erlotinib. Mol Clin Oncol. 2016; 5: 14-8.

35. Piljić Burazer M, Mladinov S, Ćapkun V, Kuret S, Glavina Durdov M. The utility of thyroid transcription factor 1 (TTF-1), napsin A, excision repair cross-complementing 1 (ERCC1), anaplastic lymphoma kinase (ALK) and the epidermal growth factor receptor (EGFR) expression in small biopsy in prognosis of patients with lung adenocarcinoma - a retrograde single-center study from Croatia. Med Sci Monit. 2017; 23: 489-97.

36. Schilsky JB, Ni A, Ahn L, Datta S, Travis WD, Kris MG, et al. Prognostic impact of TTF-1 expression in patients with stage IV lung adenocarcinomas. Lung Cancer. 2017; 108: 205-11.

37. Zhou C, Zhao J, Shao J, Li W. Prognostic relevance of TTF-1 expression in stage I adenocarcinoma. Oncotarget. 2017; 8: 107462-68.

38. Doherty MK, O'Connor E, Hannon D, O'Reilly A, Yen D, Redmond M, et al. Absence of thyroid transcription factor-1 expression is associated with poor survival in patients with advanced pulmonary adenocarcinoma treated with pemetrexed-based chemotherapy. Ir J Med Sci. 2018. doi: 10.1007/s11845-018-1839-5 (Epub ahead of print). 
39. Berghmans T, Paesmans M, Mascaux C, Martin B, Meert AP, Haller A, et al. Thyroid transcription factor 1--a new prognostic factor in lung cancer: a meta-analysis. Ann Oncol. 2006; 17: 1673-6.

40. Qian HH, Xu TS, Cai XQ, Ji TL, Guo HX. Prognostic value of TTF-1 expression in patients with non-small cell lung cancer: A meta-analysis. Clin Chim Acta. 2015; 451: 208-14.

41. Panic N, Leoncini E, de Belvis G, Ricciardi W, Boccia S. Evaluation of the endorsement of the preferred reporting items for systematic reviews and meta-analysis (PRISMA) statement on the quality of published systematic review and meta-analyses. PLoS One. 2013; 8: e83138.

42. Sterne JA, Sutton AJ, Ioannidis JP, Terrin N, Jones DR, Lau J, et al. Recommendations for examining and interpreting funnel plot asymmetry in meta-analyses of randomised controlled trials. BMJ. 2011; 343: d4002.

43. Eagger M, Davey Smith G, Schneider M, Minder C. Bias in meta-analysis detected by a simple graphical test. BMJ. 1997; 315: 629-34.

44. Sormunen R, Pääkkö P, Kaarteenaho-Wiik R, Soini Y. Differential expression of adhesion molecules in lung tumours. Histopathology. 2007; 50: 282-4.

45. Li L, Li X, Yin J, Song X, Chen X, Feng J, et al. The high diagnostic accuracy of combined test of thyroid transcription factor 1 and Napsin A to distinguish between lung adenocarcinoma and squamous cell carcinoma: a meta-analysis. PLoS One. 2014; 9: e100837.

46. Maemondo M, Inoue A, Kobayashi K, Sugawara S, Oizumi S, Isobe H, et al. Gefitinib or chemotherapy for non-small-cell lung cancer with mutated EGFR. N Engl J Med. 2010; 362: 2380-8.

47. Shanzhi W, Yiping H, Ling H, Jianming Z, Qiang L. The relationship between TTF-1 expression and EGFR mutations in lung adenocarcinomas. PLoS One. 2014; 9: e95479.

48. Sun PL, Seol H, Lee HJ, Yoo SB, Kim H, Xu X, et al. High incidence of EGFR mutations in Korean men smokers with no intratumoral heterogeneity of lung adenocarcinomas: correlation with histologic subtypes, EGFR/TTF-1 expressions, and clinical features. J Thorac Oncol. 2012; 7: 323-30. 